ECOLOGICA, Vol. 28, No 103 (2021), 378-386

https://doi.org/10.18485/ecologica.2021.28.103.7

Оригинални научни рад

УДК: 338.1:502.131.1

\title{
Практични аспекти Зелене економије
}

\section{Practical Aspects of Green Economy}

\author{
Радомир Стојковић ${ }^{1 *}$, Данијел Васиљевић \\ 1 Факултет за инжењерски менаџмент, Булевар војводе Мишића 43, 11000 Београд, Србија / \\ Faculty of Engineering Management, Bulevar vojvode Misića 43, 11000 Belgrade, Serbia \\ 2Град Врање - Градско Веће, Краља Милана 1, 17500 Врање, Србија / \\ City of Vranje - City Council, Kralja Milana 1, 17500 Vranje, Serbia \\ *Аутор за преписку / Corresponding author
}

Рад примљен / Received: 20.12.2020, Рад прихваћен / Accepted: 07.08.2021.

Сажетак: Аутори се у раду баве проблематиком зелене економије. Представљајући теоријски аспект овог појма и концепта настоје да конкретно и практично укажу на области примене концепта зелене економије. Водећи се дефиницијама најкредибилнијих глобалних институција, чије је делокруг фукционисања одрживи развој, заштита животне средине и сама зелена економија, али и признатих теоретичара, аутори представљају практичну сферу примене зелене економије. Идеја о „зеленом одрживом развоју“ стара је неколико деценија. Међутим, у срж економске теорије и праксе избија тек на почекту 21. века са појавом бројних еколошких проблема и кризних ситуација. Прихватајући принципе зелене економије стварају се услови за одговоран одрживи развој. Од зелене пољопривреде до зеленог инвестирања носиоцима политичке и економске власти на располагању су области функционисања којима се ствара основа за одрживи развој у свим сфрерама привреде и друштва. Аутори у раду представљају и резултате националног истраживања, у ком су директно и индиректно били укључени, о инкорпорирању циркуларне економије као интегралног елемента зелене економије у стратешке и развојне политике и планове јединица локалне самоуправе.

Кључне речи: зелена економија, циркуларна економија, одржив развој, природни ресурси, обновљиви извори.

Abstract: The authors deal with the issue of green economy. Presenting the theoretical aspect of this concept and the concept of work gives a concrete and practical involvement in the field of application of the concept of green economy. Guided by the definitions of the most credible global institutions, the work on the functioning of the sustainable development, environmental protection and the green economy itself, but also recognized theorists, the authors represent the practical sphere of application of the green economy. The idea of "green sustainable development" is several decades old. However, in core economic theory and practice, it erupted only at the beginning of the 21 st century with the most favorable number of environmental problems and crisis situations. Accepting the principles of the green economy creates the conditions for responsible sustainable development. From green agriculture to green investment, policy makers and economic authorities have at their disposal areas of functioning that create the basis for sustainable development in all spheres of the economy and society. The authors present the results a national research, in which they were directly and indirectly involved, on the incorporation of circular economies as integrated element of the green economy in strategic and development policies and plans of local self-government units.

Keywords: green economy, circular economy, sustainable development, natural resources, renewables resources.

${ }^{1}$ orcid.org/0000-0001-9216-4149, e-mail: radomir.lale@gmail.com

2orcid.org/0000-0001-6920-8051, e-mail: dnjl.vsljvc@gmail.com 


\section{УВОД / INTRODUCTION}

Зелена економија представља концепт увођења чистих технологија, иницирајући промене у свету крупног капитала и светских корпорација у напуштању традиционалних облика пословања и уважавању питања заштите животне средине као значајних елемената корпоративне политике. Концепт зелене економије је релативно новијег датума. Разлог увођења у теорију и праксу бројних научних дисциплина лежи у чињеници да традиционалне индустрије своју производњу заснивају на простој експлоатацији природних ресурса. Под утицајем техничко-технолошких, безбедносних и нарочито еколошких фрактора експлоатација природних ресурса (обновљивих и необновљивих) добија нова значења и перспективе. У том контексту, под концептом „зелена економија“ подразумева се широк дијапазон опција - од постојећих и познатих, али и нових и још недокучених врста енергетских ресурса, до нових погледа на свет чији глобални темељ ти ресурси чине.

Зелена економија нуди респектабилне одговоре на питања о суштинској повезаности енергије, енергетске ефикасности, производње, одрживог очувања животне средине и високотехнолошког контекста савременог начина живљења. Због ширине самог концепта, не постоји јединствена и универзална дефиниција зелене економије. Под овим термином подразумева се „економија која настоји да побољша људско благостање и смањи неједнакост, уз истовремено смањење штетних људских утицаја на животну средину (Newton, A., Cantarello, E., 2014, p. 2). Ова и све остале дефиниције проистекле су из дефиниције коју је формулисао Програм Уједињених нација за заштиту животне средине. Коалиција за зелену економију, као фрорум глобалног карактера, овај термин дефинише као „еластичну економију која омогућава квалитетнији живот свих учесника на тржишту у оквиру еколошких граница и капацитета Земље“ (The Green Economy Pocketbook, 2012). Из перспективе економске философрије ово је једна од најпримеренијих дефиниција (философско схватање) зелене економије.

Огроман број дефиниција базиран је на темељу закључка Конференције Уједињених Нација о животној средини и развоју одржане у Рио де Жанеиру 1992. године и Агенде 21 као стратешког глобалног документа који је имао за циљ стварање одговорне и одрживе економије на еколошки прихватљивим карактеристикама. У овом контексту, Програм Уједињених нација за животну средину на зелену економију гледа као на „економију чији резултати доводе до побољшања људског благостања и социјалне једна- кости, уз истовремено изразито смањење ризика по животну средину“ (Towards a Green Economy, 2011). На основу овог стратешког документа, у наредним годинама издиференциране су области примене концепта зелене економије о којима ће у даљем тексту бити речи.

Иако је сам термин „зелена економија“ формулисан још 1972. године на Конференцији Уједињених нација о човековој средини у Стокхолму, значај ове философије добија на интензитету на прелазу из 20. у 21. век. Инциденти индустријске и еколошке природе у последњих 30-так година проблематику заштите животне средине и развоја зелене економије ставили су у епицентар светске стручне и научне јавности.

Крајем 2015. године на нивоу Европске уније донет је Акциони план за циркуларну економију (Circular Economy Action Plan, 2015) што је била полазна основа за транзицију из линеарне ка циркуларној економији. Тиме ова проблематика постаје приоритет у развојном смислу Европске уније. Под процесом транзиције ка циркуларној економији подразумева се одржавање вредности производа, материјала и ресурса у оквиру економије на што дужи рок. Овај процес за резултат има смањено стварање отпада, а то је веома битно, јер ЕУ настоји да развије одрживу, нискоугљеничну економију која економично користи своје ресурсе и конкурентна је. Тиме се, сматрају носиоци власти на нивоу ЕУ, ствара конкурентно одржива предност европске привреде.

Циркуларност настоји да открије све могућности за промоцију коришћења материјала по систему затворене петље и ланца економичности коришћења ресурса уз системски приступ и преко комплетног ланца вредности. Иста се заснива на дизајнирању производа чија ће примена бити вишеструка и временски дужа, као и поновну производњу производа након истека рока трајања. Детаљно, ово је представљено у, већ поменутом, Акционом плану за циркуларну економију Европске уније. На овај начин избећи ће се стварање новог отпада у производњи и ланцу снабдевања. Сматра се да се применом овог концепта осигурава ефикасност коришћења природних ресурса, ствара атмосфрера за отварање нових радних места, долази до промоције и унапређења једнакости међу популацијом и утиче на одрживост целокупног система. Овај приступ лако је применљив у примарном сектору, али и екстрактивним индустријама уколико постоји подстицајни политички оквир (The inclusive green economy in EU development cooperation, 2018). Поред тога, подстичу се зелене инвестиције и сталне иновације. Основа циркуларне економије је управљање 
отпадом на основу којег се успоставља категоризација и хијерархија отпада у практичном контексту. Хијерархија управљања отпадом у оквиру ЕУ концептуално је предвиђена петим делом Акционог плана циркуларне економије.

Потенцијал зелене економије је велики. Од транзиције ка циркуларној и зеленој економији носиоци власти на нивоу Европске уније очекују повећање конкурентности целокупне економије ЕУ и остварење других бенефита. Под другим бенефитима се, пре свега, мисли на заштиту предузећа од десицита природних (обновљивих и необновљивих) ресурса и променљивих цена. На овај начин обезбеђује се континуираност пословања, стварају се нове пословне могућности, подстиче се иновативност и ефикасност у производњи и потрошњи, што у крајњој мери доводи до стварања нових радних места и смањења незапослености. На новим радним местима тј. зеленим пословима ангажује се радна снага најразличитијих образовних профила, што је из перспективе ЕУ веома битно јер се остварује социјална оправданост зелене економије.

Визија Европске уније о инклузивној зеленој економији базира се на три глобална аспекта. Реч je o:

1. економском аспекту;

2. еколошком и

3. социјалном аспекту.

Економски аспект подразумева економију која на дуги рок обезбеђује раст и развој и заснива се на ефикасном искоришћавању ресурса и новом одрживом обрасцу производње и потрошње. У еколошком контексту, зелена економија настоји да очува природни капитал, инвестира у природне ресурсе и ублажава климатске промене применом нискоугљеничних решења. Социјални аспект зелене економије огледа се у унапређењу и остварењу људског благостања, обезбеђивању пристојних радних места чиме се смањују разлике међу популацијом и редукује сиромаштво као глобални проблем.

Средњорочни план носиоца макроекономске и политичке власти на нивоу Европске уније је „да се иде ка повећању поновне употребе и рециклирања комуналног отпада на барем $70 \%$, повећање стопе рециклирања амбалажног отпада на $80 \%$ до 2030. године, као и забрана одлагања отпада који се у потпуности може рециклирати до 2025. године“ (Вуковић и др., 2020, стр. 212). Овим се остварују сва три аспекта визије ЕУ о инклузивној зеленој економији.

Циркуларна економија је ужи појам од зелене економије. У фокусу циркуларне економије је уп- рављање отпадом, затим превенција отпада и ефикасност ресурса. Како је зелена економија екстензиван појам у односу на циркуларну економију, поред поменуте три димензије, обухвата и проблематику људског благостања и отпорност еко система.

Користи од зелене економије могу бити вишеструке и велике. Студија која је рађена на територији Сједињених Америчких Држава у ауторству независне фондације указала је да зелена економија у свом пуном капацитету може остварити „преко трилион америчких долара у погледу пословних могућности“ (The inclusive green economy in EU development cooperation, 2018). Ови пројекти настоје да уштеде природне ресурсе и енергију и на тај начин створе мање отпада који ће штетити клими, биолошкој разноврсности, ваздуху, земљи и води.

\section{1. МАТЕРИЈАЛИ И МЕТОДЕ / MATERIALS AND METHODS}

Мотив за писање овог рада лежи у чињеници да је зелена економија и њен есенцијални део циркуларна економија, основни модел одрживог раста и развоја у савременим околностима. Развојни економско-привредни потенцијали ограничени су на неколико делатности. У свету реалне производње највећи повраћај уложених средстава и добитак остварује индустрија информационо-комуникационих технологија. Истовремено, ова индустрија свој раст базира на рециклажи и поновној употреби већ коришћених сировина и материјала. Овде је реч о бакру, галијуму, танталу и индијуму који се све чешће користе у неколико производних процеса, а чија је примарна експлоатација веома скупа, веома чешто штетна по природну средину и све више дефицитарна.

Теоријско и емпиријско сагледавање нове парадигме у економској философији предмет је истраживања овог рада. Исто се заснива на коришћењу, како иностране тако и домицилне литературе, најрелевантнијих теоријских и стручних радова, али и емпиријског истраживања у које су аутори директно и индиректно били укључени. Примарни циљ рада је сагледавање и представљање примера добре праксе из области циркуларне и генерално зелене економије. Аутори настоје да на целовит и конзистентан начин представе и формулишу нови развојни економски концепт који се може и мора примењивати у свим привредним секторима како би се створили услови за дугорочан и одржив развој друштва у целини. Интеракцијом теоријских сазнања и практичних достугнућа стварају се услови за разумевање комплексног односа зелене економије и 
одрживог развоја, што за крајњи циљ има отварање нових дискусија на постављену тему.

Имајући у виду дефинисан предмет и постављен циљ у раду, користећи се методом историографије наглашава се историјска повезаност и еволуција циљева и концепта одрживог развоја. Уназад три деценије се указује на процес нарушавања животне средине и потребе за одрживим и еколошки оправданим производним процесима. Анализом садржаја кредибилне научне и стручне литературе указано је на најзначајнија теоријска сазнања и претпоставке које су основ нових идеја у пракси. У том контексту указано је на дефиниције зелене економије у чијој основи се налази теоријско-практично поимање Програма Уједињених нација за заштиту животне средине овог појма. Користећи се статистичком методом аутори презентују резултате емпиријског истраживања спроведеног на територији Србије о значају и прихватљивости концепта циркуларне економије у националним оквирима. Ставови и препоруке изнесени у дискусији и закључку рада резултат су синтентизовања теоријских и стручних достигнућа и истраживања. Синтезом су, заправо интегрисани битни рашчлањени елементи појаве и доведени у контекст предмета рада.

\section{2. РЕЗУЛТАТИ И ДИСКУСИЈА / RESULTS AND DISCUSSION}

Као и сваки други аспект економије и зелена економија се суочава са одређеним изазовима. У овој области изазови добијају на значају, јер се истом решавају круцијални проблеми економије и друштва генерално. Веома често се прави, не тако драстична, али ипак грешка, поистовећивањем појма зелене економије и одрживог развоја. Ови појмови су различити и истовремено комплементарни. Повезивањем концепта зелене економије и одрживог развоја омогућује се поштовање принципа Агенде 21, као круцијалне основе „зеленог одрживог развоја“.

Анализирајући стање глобалне економије и економије генерално, Мартин Кор је указао на неколико проблема са којима се концепт зелене економије суочава. На првом месту различито је гледање на ову философију из перспективе развијених и земаља у развоју. Наиме, развијене државе морају бити ослонац земљама у развоју у процесу прихватања и имплементирања идеје зелене економије. Кор сматра да је поштовање принципа утврђених на Конференцији Уједињених нација о животној средини и развоју из 1992. године, а посебно принципа заједничких али диференцираних одговорности, од пресудне важности и значаја. Кор сматра да су развијене земље од есенцијалне важности за доношење консензуса о глобалном прихватању концепта зелене економије. По њему, најразвијеније државе моpajy:

- да преузму вођство у измени обрасца производње и потрошње;

- да домицилне развојне стратегије базирају на одрживој и зеленој пракси и

- да подстичу одржив развој у земљама у развоју како би на што једноставнији начин недовољно развијене државе примениле зелени концепт у пракси (Khor, 2012).

У самом односу високоразвијених и држава у развоју концепт зелене економије ствара нове услове за сарадњу, али и нове ризике. Главни ризик који се може јавити јесте извоз прљавих технологија под „марком зелене економије“. Земље у развоју су приморане да набављају технологију од развијених земаља, с тим што нису у могућности да обезбеде нове технологије, па прихватају и застареле и прљаве технологије из развијених држава. Зелена економија може проузроковати и проблеме у трговинским режимима земаља. Богате државе су у могућности да диктирају услове и трговинске режиме са земљама у развоју коришћењем зелене економије као услова за сарадњу. На тај начин државама у развоју намећу се пројекти које су једино индустријске и развијене државе у могућности да спроведу.

Свака нова идеја у развојном процесу суочава се са одређеним ризицима. У контексту зелене економије примарни ризик је погрешна интерпретација самог концепта. Зеленој економији се не сме приступити као једнодимензионалном концепту. Она није ни чисто економски, нити еколошки појам. Да би се употпунио и добила комплетна слика, у појам зелене економије мора се увести и друштвени аспект. То значи да концепт зелене економије поред, економске и еколошке сфере има и политички и правни и техничкотехнолошки аспект. У овом контексту, визија Европске уније о трипартитном приступу оправдана је у потпуности.

Следећи проблем са којима се идеја зелене економије суочава јесте приступ „један модел је добар за све.“ Овакав став примењују, углавном оне државе које овај концепт желе да уведу што је брже могуће, сматрајући да ће добити бенефиције међународне заједнице. Третирати све државе на исти начин у овој сорери погрешно је, јер се природни услови разликују од државе до државе. 
Зелена економије је у развијеним државама у систему субвенционисаних сектора, што значи да им домицилне јавне власти омогућују одређене повластице у производњи и промоцији идеје. Државе у развоју нису у истој ситуацији, јер се суочавају са проблемима којих у државама у развоју нема или има у занемарљивом односу. При томе, државе у развоју нису у ситуацији да производима зелене економије који су предмет увоза наметну корективне мере, јер је то супротно правилима трговинских и економских мултилатералних институција.

Заговорници зелене економије инсистирају и на одговорности развијених држава у контексту да се зелена економија не користи као оправдање за приступ новим тржиштима. Имајући у виду чињеницу да све више међународних и глобалних организација у свом опусу укључује и зелену економију, овај концепт никако не сме бити услов земљама у развоју за добијање међународне помоћи и зајмова, као ни услов за репрограмирање или отпис истих.

Инсистирајући на увођењу зелене економије у развојне програме и политике, готово све регионалне и глобалне институције и организације мултилатералног карактера у зеленој економији виде једину алтернативну идеју која води ка одрживом развоју. У том контексту, свеобухватни развојни програм мора бити заснован на интегрисаној идеји зелене економије и концепта одрживог развоја заснованог на принципа Риа и Агенде 21. На овај начин остварују се економски ефекти уз истовремено очување животне средине. У оваквој ситуација посебно треба водити рачуна о сиромашним и земљама у развоју и њиховим специфичним потребама, као и потребама будућих генерација.

Из саме дефиниције појма може се видети да је „опус“ зелене економије веома разуђен. Генерално, подручја обухвата овог појма могу се систематизовати на следећи начин и категорије: зелена пољопривреда, зелени послови, зелено гориво - обновљиви извори енергије, зелена градња, зелени транспорт, управљање отпадом, управљање водама, управљање земљиштем, управљање шумама и зелена улагања.

Зелена пољопривреда, најчешће се дефинише као „агропроизводња са смањеном или нултом употребом вештачких ђубрива и пестицида, која настоји да обнови природне ресурсе, смањи ерозију тла, побољша плодност и добрим управљањем створи услове за повећање продуктивности. Поред интегрисане производње, увелико се развијају модели пермакултуре (еколошки инжењеринг чију основу чине концепт одрживе по- љоприведе и екологије) и forest restoration agriculture (пољопривреда која омогућава обнављање шума).

Под зеленим пословима подразумева се широк спектар различитих послова у различитим секторима уз ангажовање разнолике радне снаге. Овај појам у теоријском контексту још увек није прецизно дефинисан, иако бројне организације и институције настоје да промовишу ову врсту послова. Због масовне, али и неадекватне употребе термина „зелени послови“ поједини аутори напомињу да је „појам „зелено“ изгубио значај, фрокус и вредност“ (Јанковић, 2016, стр. 257). Постоји заједнички став Међународне организације рада и Програма Уједињених нација за заштиту животне средине да се под зеленим пословима подразумевају радна места у секторима који производе зелене производе и услуге, као и занимања у зеленим процесима који су еколошки повољни (Altenburg, Assmann, 2017, pр. 53-54). Ова десиниција проширена је и идејом о пристојним радним местима и достојанственом раду, што је инкорпорирано и у Париском споразуму о климатским променама из 2015. године.

Када је реч о обновљивим изворима енергије, исти су били десринисани као трајни енергетски извори. Обновљиви извори енергије представљају ресурсе који се, углавном користе за производњу електричне или топлотне енергије. Основна карактеристика обновљивих извора енергије је константност односно цикличност обнављања. Пракса је показала да „обновљиви извори енергије доносе велике здравствене користи, обезбеђујући чисту, безбедну енергију, без негативних ефреката употребе фросилних горива." (Obnovljivi izvori energije: vodič za parlamentarce, 2013, str.10.)

Појам зелене градње се у литератури може срести и под именом зелене конструкције и/или одрживе грађевине. Агенција за заштиту животне средине Сједињених Америчких Држава на појам зелене градње гледа као на „структуре и процесе који су еколошки одговорни и који ефикасно користе ресурсе током животног циклуса саме грађевине“ (https://www.epa.gov/). Ово подразумева да сваки процес (од планирања, пројектовања, изградње, рада тј. фрункционисања зграде и процеса, до одржавања, обнове, рушења и одлагања и са њим повезане рециклаже материјала) има елементе зелене и одрживе градње. Одрживост у области зелене градње заснива се на три димензије, и то: планета, људи и профит, као обједињеног ланца снабдевања.

Највећи допринос зеленој пракси у области транспорта даје Програм Уједињених нација за животну средину. Бавећи се проблематиком зе- 
леног транспорта овај Програм инсистира на фррази „зелени и здрави транспорт“. Овим видом транспорта настоји се обезбедити „заштита од даљих климатских промена, заштита екосистема, јавног здравља, природних ресурса, али и остварење привредног раста и социјалне безбедности“ (Riding towards green economy: Cycling and green jobs - A joint report, 2017, pp. 10). Основ зеленог транспорта чине мобилност, зелена возила и мали бизнис и иновације.

Управљање отпадом све више добија на значају, како на глобалном тако и на националним нивоима. У Србији је управљање отпадом делатност од општег интереса и регулисана је републичким законом (Закон о управљању отпадом). Проблематика управљања отпадом константно је актуелна, без обзира да ли се ради о нормалним условима функционисања живота или кризним временима и ситуацијама.

Слично управљању отпадом и управљање водним ресурсима спада у приоритетне задатке националних влада. Законом о водама (Закон о водама) предвиђено је 8 начела којима се ближе регулише управљање водама у Србији. Управљање водним ресурсима није ни мало лак задатак. На националним нивоима езгистирају различите организације и институције јавног карактера и цивилног друштва које су фокусиране на овај сегмент зелене економије. Због све већег значаја вода, одређени број држава има, чак и појединачна министарства чији је делокруг послова управљање морским и копненим водама.

Управљање земљиштем се дефинише као „процес управљања употребом и развојем земљишних ресурса без обзира да ли се радило о земљишту у урбаним или руралним срединама“. Процес управљања земљиштем је мултидимензионалног карактера јер обједињује органску пољопривреду, пошумљавање, управљање водним ресурсима и пројекте еко-туризма (Larsson, 2010). У Србији је заштита земљишта регулисана законском процедуром у виду Закона о заштити земљишта (Закон о заштити земљишта). Њиме је предвиђено „смањење на минимум губитка квалитета земљишта, затим губици ерозијом, отицањем и оцеђивањем површинских и подземних вода“.

Буркартов концепт зелене економије заснован на шест принципа (Burkart, 2010) проширен је философијом управљања шумама. Шуме су препознате као један од најдеградиранијих секвенци природне средине и у том контексту је 2012. године донесена резолуција у оквиру Уједињених нација и установљен 21. март као Међународни дан шума. Очување, заштита и унапређење ста- ња шума у Републици Србији се спроводи на основу одредаба Закона о шумама (Закон о шумама) и њиме се јасно прецизира процедура гајења и коришћења шума, као и располагање шумама, али и шумским земљиштем.

Стављањем у епицентар светске стручне и научне јавности концепт зелене економије доживео је својеврсну диверсификацију. Сектор улагања и фринансијска индустрија у зеленој економији видели су могућности нових инвестиција и зарада. На тој основи фрормулисан је термин зелена улагања. Под зеленим улагањима се подразумевају инвестиције које „доприносе заштити и побољшању животне средине и екосистема." Колико је фринансијска индустрија битна за зелену економију, показује и став Задека и Флин о потреби диференцирања појмова зелено финансирање и зелене инвестиције. Наиме, они сматрају да је зелено финансирање шири појам и у своју дефиницију укључује зелено инвестирање. Зелено финансирање обухвата и оперативне трошкове као што су трошкови припреме пројекта, анализе будућег посла, обезбеђења земљишта и сл. а који нису елементи појма зелене инвестиције (Zadek, Flynn, 2013). Из перспективе Европске уније, зелена улагања су улагања која за крајњи циљ имају смањење емисије гасова са ефектом стаклене баште. Улагања се односе на већ постојеће фабрике које чувају природне ресурсе, дистрибуирају обновљиве изворе енергије и сл. али и на сектор тзв. нових технлологија. Све ово треба да доведе до испуњење дугорочног плана, формулисаног у постојању Европског зеленог плана, о нултој нето емисији угљен-диоксида. (The European Green Deal).

Сиким је индијска савезна држава која је прва успешно завршила транзицију на $100 \%$ органску пољопривреду, односно са линеарне на зелену економију. Савезна власт Индије је предузела значајне кораке како би помогла пољопривредницима да пласирају своје производе. Под руководством Државне федерације задруга за снабдевање и маркетинг (Sikkim State Co-operative Supply and Marketing Federation - SIMFED) 170 задруга купује производе директно од пољопривредника и пласира их на домицилно тржиште.

GoodWork je on-line платформа која промовише идеју стварања добрих радних места коју је покренула Канадска мрежа за животну средину (The Canadian Environmental Network - RCEN) током 2001. године. Носиоци ове идеје залажу се за зелени, здрави и одрживи свет. Раде на повезивању зелених инвеститора, незапослених и појединаца и организација које желе да унапреде стање животне средине. Политички, идеолошки, 
верски су независни и неутрални, јер је изградња одрживог света могућа само уједињеним деловањем и функционисањем.

На североистоку шкотске обале инсталирана је прва фрарма плутајућих ветрењача. Шкотска је глобално позната по производњи електричне енергије из обновљивих извора, а пројекат плутајућих ветрењача само употпуњује план одрживости овог сектора и шкотске привреде. Hywind пројекат обезбеђује струју за скоро 20.000 домаћинстава. Пуштањем у рад овог система, напајање преко 50\% шкотског електро-енергетског система струјом обезбеђује се путем обновљивих извора енергије. На територији Србије, конкретније Шапца, инсталирана је соларна фотонапонска централа капацитета 3 киловата. Овај пројекат дело је Енергетске задруге „Сунчани кровови Шапца“ и за циљ има снабдевање енергијом зграде на којој је инсталиран систем.

Шпанска компанија YEGO (https://www.rideyego .com/barcelona) je start-up пословни подухват који је веома брзо прихваћен од стране Каталонаца иако је на тржишту тек 5 година. Компанија се бави изнајмљивањем електричних скутера ретро изгледа названих YEGO искључиво преко мобилне апликације. Како су скутери електричног карактера, раде бешумно и без емисије угљендиоксида, прави су пример зеленог транспорта. Оснивачи компаније су предвидели и ширење пословања, не само на територији Шпаније, већ и целе Европе, путем франшизног пословања. Слична је ситуација и са „ElectriCitybus“ градским аутобусом, производом који је заједнички успех Siemens-a и италијанске компаније Rampini. Аутобус покрећу батерије које једним пуњењем могу обезбедити око 150 километара „зелене вожње“.

BlueCity (https://www.bluecity.nl/about-bluecity/) ce сматра међународним лидером у промоцији циркуларне економије. Холандска национална платформа за циркуларне предузетнике и врло видљив локални акцелератор који промовише циркуларну и зелену економију, са визијом „свет без отпада“: Компанија је у координацији са водећим економско-еколошко-политичким институцијама Европске уније водећи носилац два огромна (глобална) пројекта. Ради се о пројектима рециклаже пластике и мапирања и смањења отпада у троуглу храна-енергија-вода у градовима широм Европе, Африке и Јужне Америке.

У непосредном домицилном окружењу, у Хрватској, покренута је web платформа Freewa (https://freewa.org), мобилна апликација за мапирање бесплатних локација воде за пиће широм света и еко боца за воду са врећицом од рециклираног материјала. Freewa боца је направљена од стакла, а врећа од рециклираних пластичних боца које се могу поново рециклирати.

„Нова шума“ (https://www.cmelak.cz/novyprales/) је јединствени пројекат, који је покренут током 2004. године од стране чешке невладине организације „Бумбар“. Резултат пројекта је трансформација шумског подручја, где је преовладавала монокултура смрче у мешовиту шуму. Десетине хиљада садница букве, јеле и јавора је засађено на простору од 35 хектара.

Револуција у области банкарства и финансијске индустрије догодила се је оснивањем Green Investment Bank (https://www.greeninvestme ntgroup.com/) 2012. године. Банка је основана од стране британске владе са циљем привлачења ликвидних средстава из приватног сектора и интензивнијег ангажовања приватног сектора у области зелене економије, а све у циљу унапређења животне средине. Банка настоји да подржи и омогући даља истраживања производа из четврте индустријске револуције. Посебно интересовање Банка је исказала за пројекте у области енергетике, као што је револуционарни пројект складиштења енергије, али и искоришћења потенцијала ветра, мора и сунчеве енергије.

Током 2019. године спроведено је истраживање капацитета локалних привреда за прелазак са линеарне на циркуларну економију. (Analiza kapaciteta jedinica lokalne samouprave u pogledu stvaranja uslova za prelazak na cirkularnu ekonomiju, 2019.). Истраживање је имало национални карактер, а спроведено је у виду анкете која је имала за циљ да укаже на ставове јединица локалне самоуправе о увођењу концепта циркуларне економије као круцијалног елемента зелене економије, у локалне привредне системе. Стална конференција градова и општина Србије и Немачко друштво за међународну сарадњу били су носиоци пројекта.

Циљ истраживања био је утврђивање нивоа познавања концепта циркуларне економије носилаца економско-политичке власти на нивоу локалних самоуправа и интегрисаност идеје циркуларне и зелене економије у политике и стратегије локалних самоуправа. Истраживање је обухватило 121 испитаника из 94 града и општине у Србији.

Резултати истраживања показали су да су носиоци власти на локалном нивоу у Србији упознати са концептом циркуларне економије. Наиме, 71,1\% испитаника позитивно је одговорило на питања из области циркуларне економије и заштите животне средине. Када је реч о градовима који имају преко 100.000 становника овај проценат је виши. Скоро 82\% испитаника 
упознато је са принципима и циљевима циркуларне економије. Много битнији резултат анкете јесте податак да, тек 3\% од укупног броја локалних самоуправа у свом организационом органограму поседује јединице (одељења) које на директан и/или индиректан начин обрађују проблематику циркуларне економије. У већем броју локалних стратегија развоја ова проблематика није ни препозната као потенцијално развојни сегмент локалних привреда.

Грађанске иницијативе су препознате као подстицајни фрактор у развоју зелене идеје. Као интересне групе око којих су окупљени поједници различитих образовних структура, грађанске иницијативе имају моћ покретања идеја и ангажовања висококвалификоване и стручне радне снаге на волонтерској основи. Ово је веома битно, јер већина локалних самоуправа у Србији није финансијски способна да ангажује тако широку групацију људи без финансијске потпоре. Поред овога, едукација локалног становништва је од велике важности за увођење циркуларне и зелене праксе у рад локалних самоуправа. Само промена свести грађана о животној средини и брига о истој могу дати позитивне резултате.

Делатност производње амбалаже и амбалажног отпада је најпрепознатљивија међу испитаницима. Ово се може објаснити тиме да носиоци власти на локалном нивоу нису довољно заинтересовани за циркуларну економију, јер је ова делатност само један делић у укупној философији зелене економије. Занемаривање квалитета воде и земљишта је значајно. Процес дефорестације је све израженији, а водотоковима се не придаје велика пажња све док се не деси велики инцидент.

За дубље прихватање и развој циркуларне и зелене економије на националном нивоу Републике Србије неопходно је и учешће приватног капитала и сектора у овој области. Поред проблематике управљања отпадом интерес приватног капитала може се остварити улагањем у обновљиве изворе енергије, чиме би се фокус са циркуларне економије пребацио на шири аспект, на зелену економију. Несумњиво је да Србија има добрих изгледа у погледу развоја комплетног концепта зелене економије. Поједини природни ресурси, као што су извори слатких и минералних вода, затим подручја са великим бројем сунчаних и ветровитих дана отварају нове пословне могућности. Ови природни потенцијали су недовољно искоришћени, неки чак и препуштени небризи. Помоћ државних органа власти у смислу промоције зелене економије, природних потенцијала и субвенционисања пројеката из ове области за резултат би имао отварање нових профи- тоносних организација и радних места. Финансијска индустрија би, такође остварила одређене бенефите, јер може бити директно или индиректно укључена у процес финансирања зелених пројеката.

\section{ЗАКЉУЧАК / CONCLUSION}

Зелена економија представља релативно нов концепт у економији, који пре свега предлаже помак од фокусирања на економском расту ка „стабилној економији“. Економисти који се баве проблематиком одрживог развоја, односно зеленом економијом и њеним интергалним елементима, настоје да укажу да је концепт зелене економије једини начин за дугорочан и одрживи развој. Правилно и ефикасно ескплоатисање и управљање природним ресурсима ствара предуслове за извесност функционисања будућих генерација. Питање ресурса је пресудно, а посебну пажњу треба посветити брзини трошења необновљивих природних ресурса. У фокусу зелене економије је квалитет робе, начин њене производње, коришћење и утицај истих на природну средину. Четврта индустријска револуција индиректно промовише значај зелене економије и ставља је у епицентар, не само научне сфере, већ и политичке односно ставља је међу приоритетне задатке носилаца макроекономске и политичке власти.

Постоји реална потреба, самим тим и прилика да зелена економија иницира уравнотежен и еколошки приступ економији који је развијен у последње две деценије. Када је у питању Србија треба нагласити чињеницу постојања разлика између републичког и нивоа локалних самоуправа. Декларативно Република Србије се залаже за увођење и праксу зелене економије. Међутим, на нижим нивоима власти, пре свега у контексту општина и градова са мање од 100.000 становника (који чине велику већину у територијалнополитичкој организацији) не постоји иницијатива за покретање пројеката из области циркуларне и зелене економије. Идеју зелене економије заступају, барем декларативно, јавна комунална предузећа без покретања реалних и практичних иницијатива. Због високих трошкова приватни капитал је недовољно заинтересован за транзицију ка зеленој економији, конкретније зеленој градњи, индустрији и финансирању. Резултати поменутог националног истраживања говоре да су жене, као посебна циљна група, далеко заинтересованије и укљученије у зелене пројекте. На основу истог, може се извући и закључак да би комплетан процес зелене економије био прихватљивији уколико би постојала помоћ локалних самоуправа 
приликом покретања star up бизниса из ове сфере. Другим речима, субвенционисање пројеката из области зелене економије на нивоу јединица локалне самоуправе омогућило би веће интересовање и ангажовање приватног капитала у овој области.

\section{ЛИТЕРАTУРA / REFERENCES}

[1] Altenburg, T., Assmann, C. (Eds.), (2017). Green Industrial Policy. Concept, Policies, Country Experiences, UN Environment; German Development Institute/Deutsches Institut für Entwicklungspolitk (DIE), Geneva, Bonn

[2] Analiza kapaciteta jedinica lokalne samouprave u pogledu stvaranja uslova za prelazak na cirkularnu ekonomiju, (ur. Gluščević, M., Kaluđerović, Lj. 2019). Deutsche Gesellschaft fürInternationale Zusammenarbeit (GIZ) GmbH i Stalna konferencija gradova i opština Srbije, Beograd.

[3] Bogetić, S., Đorđević, D., Ćočkalo, D., Đorđević, Lj., Bakator, M. (2021). Cirkularna ekonomija i izazovi globalnog tržišta, Ecologica, 28(101), str. 65-71.

[4] Burkart, K. (2010), How do you define the "green“ economy?". MNN - Mother Nature Network.

[5] Vuković, A., Riznić, D., Vuković, M. (2020). Cirkularna ekonomija u funkciji regeneracije prirodnih resursa, Ecologica, 27(98), str. 209-216.

[6] Zadek, S., Flynn, Cassie. (2013). South-Originating Green Finance: Exploring the Potential, The Geneva International Finance Dialogues, Geneva

[7] Закон о управљању отпадом, Службени гласник Републике Србије, бр. 36/2009, 88/2010, 14/2016 и 95/2018 - др. Закон

[8] Закон о водама, Службени гласник Републике Србије, бр. 30/2010, 93/2012, 101/2016, 95/2018 и 95/2018 - др. Закон

[9] Закон о шумама, Службени гласник Републике Србије, бр. 30/2010, 93/2012, 89/2015 и 95/2018 - др. Закон

[10] Закон о заштити земљишта, Службени гласник Републике Србије, бр. 112/2015

[11] Јанковић, J. (2016). Специфиичне мере „озелењавања" осигурања за случај незапослености, Зборник радова Правног факултета у Нишу, 54(73), str. 253-267.

[12] Khor, M. (2012). Preliminary Notes on the Green Economy, in the Context of Sustainable Development, Presentation of the Executive Director of the
South Centre in the Panel of the Green Economy at the Inter-sessional debates of Rio Plus 20.

[13] Larsson, G. (2010). Land Management as Public Policy, University Press of America,

[14] Newton, A., Cantarello, E. (2014). An introduction to the green economy: Science, systems and sustainability, Routledge, London

[15] Obnovljivi izvori energije: vodič za parlamentarce, (2013). Program Ujedinjenih nacija za razvoj

[16] Riding towards green economy: Cycling and green jobs - A joint report (2017). by UN EnvironmentWHO-UNECE, United Nation Environmental Program

[17] Towards a Green Economy: Pathways to Sustainable Development and Poverty Eradication - A Synthesis for Policy Makers, (2011). United Nations Environmental Progaramme, доступно на: www.unep.org/greeneconomy, датум приступа: 20.03.2021.

[18] The Green Economy Pocketbook - The case for action, (2012). Green Economy Coalition, доступно на:

https://www.greeneconomycoalition.org/assets/re ports/GEC-Reports/Green-Economy-Pocketbookthe-case-for-action_0.pdf (01.04.2021.)

[19] The inclusive green economy in EU development cooperation - An innovative approach at the intersection of the EU's Planet, People and Prosperity objectives, (2018). Directorate-General for International Cooperation and Development European Commission, Brussels \& Luxembourg.

[20] The European Green Deal: доступно на: https://eur-lex.europa.eu/legalcontent/EN/TXT/?qid=1596443911913\&uri=CELE X:52019DC0640\#document2 (03.04.2021.)

[21] http://simfed.in/General/Default.aspx

[22] https://freewa.org

[23] https://rcen.cal

[24] https://www.bluecity.nl/about-bluecity/

[25] https://www.cmelak.cz/novy-prales

[26] https://www.epa.gov/

[27] https://www.goodwork.ca/

[28] https://www.greeninvestmentgroup.com/

[29] https://www.rideyego.com/barcelona/

[30] Closing the loop - An EU action plan for the Circular Economy, (2015). European Commission, Brussels/. 